\title{
Maternal nutritional status in diabetes mellitus and neonatal characteristics at birth
}

\author{
Estado nutricional materno no diabetes mellitus e características neonatais ao nascimento \\ Estado nutricional materno en diabetes mellitus y características neonatales al nacimiento
}

'Hospital de Clínicas de Porto Alegre. Porto Alegre, Rio Grande do Sul. Brazil.

"Universidade Federal do Rio Grande do Sul. Porto Alegre, Rio Grande do Sul, Brazil.

How to cite this article:

Pedrini DB, Cunha MLC, Breigeiron, MK. Maternal nutritional status in diabetes mellitus and neonatal characteristics at birth. Rev Bras Enferm. 2020;73(Suppl 4):e20181000. doi: http://dx.doi.org/10.1590/0034-7167-2018-1000

\section{Corresponding author: Márcia Koja Breigeiron E-mail: mbreigeiron@gmail.com}

EDITOR IN CHIEF: Dulce Aparecida Barbosa ASSOCIATE EDITOR: Prsicilla Valladares Broca

Submission: 23-02-2019
Approval: 16-11-2019

\section{ABSTRACT}

Objectives: to analyze the nutritional status of women with diagnosis of Diabetes mellitus in pregnancy and the newborns' characteristics in relation to health conditions at birth Methods: transversal study with data from 394 electronic medical charts (197 newborn and 197 mothers), between 2017 and 2018. Descriptive and analytical statistics. Results: there was prevalence of women with Gestational Diabetes $(78.2 \%)$, followed by Type II Diabetes (13.7\%) and Type I Diabetes (8.1\%), and of term births (85.3\%) and cesarean deliveries (54.8\%). Type I Diabetes was associated to earlier gestational age at birth $(p>0.001)$ and obesity during pregnancy was associated to higher birth weight of newborns $(p=0.024)$. Clinical complications occurred in $37.6 \%$ of newborns. Among complications, Type I Diabetes was associated with respiratory disorder $(p=0.005)$, and prematurity was associated with mother's overweight/obesity $(p=0.010)$. Conclusions: we strongly advise about the need of metabolic and nutritional control during gestations that course with Diabetes mellitus, due occurrence of negative consequences to the newborn's health at birth.

Descriptors: Newborn; Diabetes Gestational; Neonatal Nursing; Glycemic Index; Nutritional Status.

\section{RESUMO}

Objetivos: analisar o estado nutricional de mulheres com diagnóstico de Diabetes mellitus na gestação e as características neonatais referentes às condições de nascimento. Métodos: estudo transversal, com dados de registros informatizados de 394 prontuários (197 de mães e 197 de seus neonatos), entre os anos de 2017 e 2018. Estatística descritiva e analítica. Resultados: prevalência de mulheres com Diabetes Gestacional (78,2\%), seguido por Diabetes Tipo II (13,7\%) e Diabetes Tipo I (8,1\%), e de neonatos a termo (85,3\%) nascidos por cesariana (54,8\%). Diabetes Tipo I foi associado a menor idade gestacional ao nascimento $(p<0,001)$ e gestantes obesas ao maior peso de nascimento $(p=0,024)$. Complicações clínicas ocorreram em 37,6\% dos neonatos. Dentre as complicações, Diabetes Tipo I foi associado a distúrbio respiratório $(p=0,005)$, e sobrepeso/obesidade maternos, à prematuridade $(p=0,010)$. Conclusões: reitera-se a necessidade do controle metabólico e nutricional na gestação com Diabetes mellitus, devido ocorrência de consequências negativas no neonato. Descritores: Recém-Nascido; Diabetes Gestacional; Enfermagem Neonatal; Índice Glicêmico; Estado Nutricional.

\section{RESUMEN}

Objetivos: analizar el estado nutricional de las mujeres diagnosticadas con Diabetes mellitus durante el embarazo y las características neonatales relacionadas con las condiciones de nacimiento. Métodos: investigación transversal con datos de registros computarizados de 394 registros médicos (197 de madres y 197 de sus recién nacidos), entre 2017 y 2018. Estadísticas descriptivas y analíticas. Resultados: prevalencia de mujeres con Diabetes Gestacional (78.2\%) seguido de Diabetes Tipo II (13.7\%) y Diabetes Tipo I (8.1\%), y recién nacidos a término (85.3\%) nacidos por cesárea (54,8\%). Diabetes Tipo I se asoció con una menor edad gestacional (EG) al nacer $(p<0.001)$ y mujeres embarazadas obesas con mayor peso al nacer $(\mathrm{p}=0.024)$. Las complicaciones clínicas ocurrieron en el $37.6 \%$ de los recién nacidos. Entre las complicaciones, Diabetes Tipo I se asoció con trastorno respiratorio $(p=0.005)$ y sobrepeso/obesidad materna en la prematuridad $(p=0.010)$. Conclusiones: se reitera la necesidad del control metabólico y nutricional durante el embarazo con Diabetes mellitus, debido aparición de consecuencias negativas en el recién nacido.

Descriptores: Recién Nacido; Diabetes Gestacional; Enfermería Neonatal; Índice Glucémico; Estado Nutricional 


\section{INTRODUCTION}

Diabetes mellitus (DM) pathology is a deficiency in insulin secretion and/or action, with consequent hyperglycemia and changes in carbohydrate, lipid, protein and electrolyte metabolism $^{(1)}$. The diagnosis of DM is based on measurements of capillary blood glucose: two fasting blood glucose levels equal to or greater than $126 \mathrm{mg} / \mathrm{dL}^{(2)}$.

Diabetes mellitus can be classified into: type I diabetes mellitus (DM I) - characterized by marked hyperglycemia and abrupt onset; type II diabetes mellitus (DM II) - with milder symptoms and insidious onset; and gestational diabetes mellitus (GDM) associated with insulin resistance and/or pancreatic beta cell insufficiency in meeting the body's demand for insulin ${ }^{(1-3)}$ and first diagnosed during pregnancy, which may or may not persist after delivery ${ }^{(3)}$. World wide, the prevalence of GDM is $16.2 \%$, and in Brazil it is of $18 \%^{(4-5)}$. The International Diabetes Federation estimates that one out of every six births is from women with some form of pregnancy hyperglycemia, and that among all cases of DM in pregnancy (DM I, DM II, and GDM), the majority $(85 \%)$ is related to $\mathrm{DMG}^{(5)}$.

When associated with pregnancy, DM I, DM II or GDM can result in maternal, fetal and perinatal impairment. Maternal hyperglycemia leads to consequent fetal hyperglycemia and hyperinsulinemia, which may cause changes at birth. A poor glycemic control is related to neonatal outcomes such as fetal macrosomia, prematurity, respiratory and cardiac disorders, as well as metabolic, hematological and neurological complications ${ }^{(6)}$.

Nutritional status and metabolic control in pregnancy are important factors for a proper course of pregnancy and maintenance of mother's and child's health. In the context of DM, tracking the pathology and a suitable maintenance of glycemic levels in pregnancy contribute to minimize the risk of maternal-fetal and postnatal complications ${ }^{(7)}$.

Although the pathophysiological aspects of this topic have been widely studied, there is still a gap to be explored regarding the association of maternal DM and newborns' birth conditions. Studying this association can provide a better understanding of possible complications in newborns arising from an increasingly common pathology in society.

\section{OBJECTIVES}

To analyze the nutritional status of women diagnosed with diabetes mellitus (DM) during pregnancy and the neonatal characteristics related to birth conditions.

\section{METHODS}

\section{Ethical aspects}

This study is in line with the current ethical recommendations in Brazil for conducting research with humans, according to Resolution number 466 of December 12, 2012, of the National Health Council( ${ }^{(8)}$. The study was approved by the Research Ethics Committee of the Hospital de Clínicas de Porto Alegre, on May 8, 2017, under number 2,052,113.

\section{Design, period and place of study}

Cross-sectional and retrospective study. Data was collected from medical records of mother-infant pairs admitted to inpatient units of the Hospital de Clínicas de Porto Alegre from January 1, 2017 to May 31, 2018. The Strengthening the Reporting of Observational Studies in Epidemiology (STROBE) initiative was followed in the study.

\section{Population or sample; inclusion and exclusion criteria}

The population consisted of mothers (275) with prenatal diagnosis of DM I, DM II or GDM (according to medical records) and their newborns (275). The medical records of both mothers and newborns were provided by the Information Systems department of the hospital, according to inclusion and exclusion criteria. Mothers aged 18 years or older without associated pathologies (chronic respiratory diseases, neoplasms, gastrointestinal, hepatic and infectious tract diseases, heart disease, syphilis and Human Immunodeficiency Virus positive serology) and neonates (single child) were included in the study search.

We considered the number of medical records under $4 \%$ error, 95\% confidence interval and $20 \%$ loss for sample calculation, and the estimated sample was of 402 records ( 201 for mothers and 201 for newborns).

The records were made available by the Medical and Statistical Archiving Service (SAME). Data were collected from records in the electronic medical records of mothers and newborns in August 2017, retrospectively, according to the ordering of the list granted by the hospital. Maternal data collected were those recorded for the first time in the medical records within 48 hours of admission to the inpatient unit. Newborns' data were from the interval between birth and the first hour of life. Data were extracted from medical records and transcribed to a data collection instrument containing the study variables.

\section{Study Protocol}

Maternal data of the gestational and puerperal period were collected. Data were stratified by: demographics - age, race, place of residence, education and marital status; clinical - type of DM (DMG, DM I or DM II) and treatment, body weight (Kg), height (m), blood glucose $(\mathrm{mg} / \mathrm{dL})$ verified by hemoglyotest in the first 48 hours after delivery (first record), and nutritional status. Nutritional status at the end of pregnancy was determined according to Body Mass Index (BMI - weight to height squared ratio) as the following: low weight, adequate weight, overweight and obesity ${ }^{(9)}$.

The variables related to the newborn included: gestational age (GA) in weeks and days; Apgar score; anthropometry: weight $(\mathrm{g})$, length $(\mathrm{cm})$, head circumference $(\mathrm{cm})$, thoracic perimeter $(\mathrm{cm})$, waist circumference $(\mathrm{cm})$; nutritional status (adequate for gestational age - AGA; small for gestational age - SGA; and large for gestational age $-\mathrm{LGA})^{(10)}$; vital signs: axillary temperature $\left({ }^{\circ} \mathrm{C}\right)$, heart rate (beats per minute - bpm), respiratory rate (movements per minute - $\mathrm{mpm})$; oxygen saturation (\%); blood glucose (mg/dL) verified by hemo-glucotest (first record); neonatal complications and need of resuscitation and/or hospitalization in a Neonatal 
Intensive Care Unit (NICU). Anthropometric data, vital signs and Apgar score were verified shortly after birth.

\section{Results analysis and statistics}

Data were organized in the Statistical Package for Social Sciences (SPSS) version 18.0 and analyzed by estimation of mean, standard deviation, median with interquartile intervals (25-75), relative and absolute frequency. Chi-square test and Fischer's exact test were used to investigate association between categorical variables, and the Kruskal Wallis test was used for associations with continuous variables. A p-value $<0.05$ was considered statistically significant.

\section{RESULTS}

Considering the total medical records of mothers and newborns, according to the established methodological criteria, eight medical records were excluded because they were incomplete, and the final sample was composed of 394 medical records ( 197 from mothers and 197 from their newborns).

Mothers' medical records had a prevalence of GDM diagnosis (78.2\%), followed by DM II (13.7\%) and DM I (8.1\%). Regarding nutritional status, most mothers were obese (81.2\%), followed by overweight (15.2\%) and adequate weight (3.6\%) at the end of pregnancy. The average age of mothers corresponded to $27( \pm 5.9)$ years.

As for newborns, most were male (52.3\%), full-term birth (85.3\%) and by cesarean section (54.8\%). The average GA was $38( \pm 2)$ weeks and $2( \pm 2)$ days, and birth weight of 3,415 $( \pm 685)$ grams $(\mathrm{g})$. Neonatal blood glucose median was 58 (31.25-71.25) $\mathrm{mg} / \mathrm{dL}$. These results are shown in Table 1.

Considering all newborns, $5.6 \%$ had blood glucose values $\leq 40 \mathrm{mg} / \mathrm{dL}$. However, low glycemic values were not significantly associated with the types of maternal DM ( $p=0.0630)$.

The newborns were stratified according to nutritional status in relation to GA in: AGA (68.5\%), LGA (22.9\%) and SGA (8.6\%). Regarding LGA newborns, $17.8 \%$ had birth weight above 4,000 grams. Mothers with DM I had predominantly newborns AGA $(81.5 \%)$ and LGA (27.6\%); while mothers with GDM had more LGA (35.6\%) and SGA (35.3\%) newborns.

Mothers with DM I $(p<0.001)$ and proper weight $(p=0.032)$ at the end of pregnancy had children with lower GA values (31-37.2). Gestational age of 37.1 weeks (36.0/38.6) was related to DM I and associated with hospitalization in a Neonatal Intensive Care Unit (NICU) $(p=0.0008)$. These results are shown in Table 2.

Considering the type of DM, newborns of mothers with DM I (56.3\%), DM II (48.1\%) and GDM (33.8\%) had some clinical complication ( $p=0.112$ ). Regardless of the type of complication, they were associated with neonates of overweight mothers $(p=0.037)$. Clinical complications occurred in $37.6 \%(n=74)$ of neonates as follows: respiratory disorder $(74.3 \%, \mathrm{n}=55)$; meconium gastric aspirate $(14.9 \%$, $\mathrm{n}=11)$; genital problems $(12,2 \%, \mathrm{n}=9)$; septicemia $(1.4 \%, \mathrm{n}=1)$; cardiac malformations $(2.7 \%, \mathrm{n}=2)$; clinodactyly $(4.0 \%, \mathrm{n}=3)$; single umbilical artery $(1.4 \%, n=1)$; microcephaly $(1.4 \%, n=1)$; sacral pit $(1.4 \%, n=1)$, and neonatal death within the first 24 hours $(2.7 \%, n=2)$.
Table 1 - Clinical characteristics of newborns at birth, Porto Alegre, Rio Grande do Sul, Brazil, 2017-2018

\begin{tabular}{lcc}
\hline \multirow{2}{*}{ Variables $^{\mathbf{a}}$} & \multicolumn{2}{c}{ Values } \\
& Mean \pm SD** & Min - Max \\
\hline Gestational age (weeks) & $38 \pm 2$ & $24-41$ \\
Birth weight (grams) & $3.415( \pm 685)$ & $1.540-4.890$ \\
Body length (centimeters) & $48.7( \pm 3.1)$ & $40-59$ \\
Cephalic perimeter (centimeters) & $34.2( \pm 2.1)$ & $28-38$ \\
Thoracic perimeter (centimeters) & $33.8( \pm 2.6)$ & $27-39.5$ \\
Abdominal circumference (centimeters) & $32.6( \pm 3.0)$ & $25-41$ \\
Vital Signs & & \\
$\quad$ Temperature (ㄷ) & $36.4( \pm 0.4)$ & $35.4-37.8$ \\
$\quad$ Heart rate (beats per minute) & $145( \pm 14)$ & $104-180$ \\
$\quad$ Respiratory rate (movements per minute) & $58( \pm 11)$ & $30-84$ \\
$\quad$ Oxygen saturation (\%) & $96( \pm 5)$ & $55-100$ \\
Glycemic level (mg/dL) & $58( \pm 15)$ & $25-95$ \\
\hline Note: ${ }^{*}$ Standard Deviation. & \multicolumn{2}{l}{}
\end{tabular}

Table 2 - Associations between Maternal Diabetes mellitus and neonatal characteristics, Porto Alegre, Rio Grande do Sul, Brazil, 2017-2018

\begin{tabular}{|c|c|c|c|}
\hline \multirow{3}{*}{$\begin{array}{l}\text { Maternal } \\
\text { Diabetes Mellitus }\end{array}$} & \multicolumn{3}{|c|}{ Neonatal characteristics } \\
\hline & \multicolumn{2}{|c|}{$\begin{array}{l}\text { Intensive Care Unit } \\
\text { admission } \\
(p=0.001)\end{array}$} & \multirow[t]{2}{*}{$\begin{array}{c}\text { Gestational Age } \\
\text { (weeks) }^{\mathrm{K}} \\
(\mathrm{p}<0.001)\end{array}$} \\
\hline & Yes & No & \\
\hline $\begin{array}{l}\text { Type I }(n=16) \\
\text { n (\%) }\end{array}$ & $6(37.5)$ & $10(62.5)$ & $37.1[36.0 / 38.6] a$ \\
\hline $\begin{array}{l}\text { Type II }(\mathrm{n}=27) \\
\mathrm{n}(\%)\end{array}$ & $3(11.1)$ & $24(88.9)$ & $37.9[36.6 / 39.7] \mathrm{ab}$ \\
\hline $\begin{array}{l}\text { Gestational }(\mathrm{n}=154) \\
\mathrm{n}(\%)\end{array}$ & $8(5.2)$ & $146(94.8)$ & $39.0[38.4 / 39.7] \mathrm{b}$ \\
\hline
\end{tabular}

During pregnancy, mothers used hypoglycemic drugs and/or restrictive diet for DM (86.5\%), and/or insulin (29.9\%). There was an association between insulin treatment of mothers with DM I and the need for NICU hospitalization for clinical complications $(p=0.026)$. Of the newborns, $8.6 \%$ were admitted to the NICU.

The main causes of NICU admission due to clinical complications were: respiratory disorders (64.7\%), prematurity (17.6\%), cardiac malformation (11.8\%), septicemia (5.9\%), hypoxic-ischemic encephalopathy (5.9\%), hypoglycemia (5.9\%) and poor social conditions (5.9\%). Cardiopulmonary resuscitation was required in $18.8 \%$ of neonates. Maternal overweight was associated with neonatal cardiopulmonary resuscitation and NICU admission $(p=0.021)$. Considering all causes of NICU admission, they were associated with DM I $(p=0.001)$ and maternal overweight $(p=0.017)$. When specifying the causes of NICU hospitalization, there was an association between maternal overweight/obesity and prematurity $(p=0.010)$, as well as between DM I and respiratory disorder $(p=0.005)$. Obese mothers $(81.2 \%)$ had children with higher birth weight $(p=0.024)$. About $89.7 \%$ of newborns with birth weight above 4,000 grams were born from mothers with some level of obesity. Apgar score was between 8 and 9 , in the first and fifth minutes of life, respectively. Maternal overweight was associated with lower Apgar scores in the first minute $(p=0.042)$. These results are available in Table 3. 
Table 3 - Associations between nutritional status of the mother and neonatal characteristics, Porto Alegre, Rio Grande do Sul, Brazil, $2017-2018$

\begin{tabular}{|c|c|c|c|c|c|c|c|c|c|}
\hline & \multicolumn{9}{|c|}{ Neonatal characteristics $n$ (\%) } \\
\hline & \multicolumn{2}{|c|}{$\begin{array}{c}\text { Clinical } \\
\text { complication }^{Q} \\
(p=0.037)\end{array}$} & \multicolumn{2}{|c|}{$\begin{array}{l}\text { Cardiopulmonary } \\
\text { resuscitation }^{Q} \\
(p=0.021)\end{array}$} & \multicolumn{2}{|c|}{$\begin{array}{c}\text { Neonatal Intensive } \\
\text { Care Unit admission } \\
(p=0.017)\end{array}$} & \multirow[t]{2}{*}{$\begin{array}{l}\text { Weight (grams) })^{* ; k} \\
\quad(p=0.024)\end{array}$} & \multirow{2}{*}{$\begin{array}{c}\text { GA } \\
\left(_{(w e e k s)^{* * ; K}}\right. \\
(p=0.032)\end{array}$} & \multirow{2}{*}{$\begin{array}{l}\text { Apgar 1st } \\
\text { minute }{ }^{* * ; k} \\
(p=0.042)\end{array}$} \\
\hline & Yes & No & Yes & No & Yes & No & & & \\
\hline \multicolumn{10}{|l|}{ Maternal nutritional status } \\
\hline Proper weight $(\mathrm{n}=7)$ & $0(0.0)$ & $7(100)$ & $0(0.0)$ & $7(100)$ & $1(14.3)$ & $6(85.7)$ & $2.750[2.226-3.180]$ & $38.4[33.1 ; 39.1]$ & $9[8 / 9]$ \\
\hline Overweight $(n=30)$ & $16(53.3)$ & $14(46.7)$ & 11(36.7) & $19(63.3)$ & $7(23.3)$ & $23(76.7)$ & $3.340[2.777-3.788]$ & $39.0[37.7 ; 39.7]$ & $8[7 / 9]$ \\
\hline \multicolumn{10}{|l|}{ Obesity } \\
\hline Class I $(n=45)$ & $15(33.3)$ & 30 (66.7) & $10(22.2)$ & $35(77.8)$ & $1(2.2)$ & $44(97.8)$ & $3.475[3.177-3.837]$ & $39.0[37.1 ; 39.7]$ & $8[8 / 9]$ \\
\hline Class II (n=51) & $23(45.1)$ & $28(54.9)$ & $10(19.6)$ & $41(80.4)$ & $5(9.8)$ & $46(90.2)$ & 3.475 [3.070-3.895] & $38.6[37.5 ; 39.7]$ & 8 [8/9] \\
\hline Class III $(n=64)$ & $20(31.3)$ & $44(68.8)$ & $6(9.4)$ & $58(90.6)$ & $3(4.7)$ & $61(95.3)$ & $3.462[3.113-3.980]$ & $39.3[38.6 ; 40.0]$ & $9[8 / 9]$ \\
\hline
\end{tabular}

\section{DISCUSSION}

The main results of this study were: prevalence of cesarean births and maternal obesity at the end of pregnancy; lower GA and need for NICU admission were related to DM I; clinical complications, lower Apgar score, need for neonatal cardiopulmonary resuscitation and hospitalization in the NICU were related to maternal overweight; and higher birth weight was related to maternal obesity. Among the causes of NICU admission, there was an association between prematurity and maternal overweight or obesity, as well as between respiratory disorder and DM I. Diabetes mellitus treatment with insulin was a preventive factor for NICU admission.

Regarding cesarean section rate, previous data show lower ${ }^{(11-15)}$ or higher ${ }^{(10-17)}$ rates of cesarean section values involving puerperal women with DM, as well as values similar to those in this study $(54.8 \%)^{(18-19)}$, and also GA values close to 38 weeks $^{(11,18-22)}$ associated with $\mathrm{DM} \mathrm{I}^{(19,23)}$.

Regarding prematurity, the literature describes a higher percentage of premature newborns in pregnant women with $\mathrm{GDM}^{(17,24)}$. However, mothers diagnosed with DM but undergoing drug treatment have a lower chance of prematurity ${ }^{(25)}$. Association between gestational age and maternal BMI is also reported in the literature ${ }^{(10)}$ with a higher frequency of premature births in obese pregnant women.

A study ${ }^{(25)}$ with neonates of pregnant women with GDM has shown prevalence of Apgar score below 7 in the first minute, and this score (first and fifth minutes) may be associated with maternal GDM.

Similar values of neonatal blood glucose were found in a study ${ }^{(26)}$ conducted with pregnant women with GDM treated with insulin or metformin. In line with data from our study, there was a low frequency of newborns with blood glucose $\leq 40 \mathrm{mg} / \mathrm{dL}$ at birth $\left(5.6 \%{ }^{(24)}, 6.3 \%{ }^{(25)}\right.$ and up to $\left.35 \%^{(11)}\right)$, although associated with maternal diagnosis of $\mathrm{GDM}^{(24-25)}$.

Neonatal weight was like that of studies involving $\mathrm{GDM}^{(10,18,22,26)}$. Corroborating the findings of this study, data from previous studies show association between maternal BMI and neonatal weight ${ }^{(10,21-22)}$, with a higher proportion of LGA births in obese pregnant women ${ }^{(10-11,15,21-22,27)}$. Obese pregnant women would be 3.5 times more likely to have LGA newborn compared to those with adequate weight ${ }^{(10)}$. In addition, obesity and DM may be considered predictive factors of fetal macrosomia ${ }^{(10,15)}$. Studies ${ }^{(10,15,21)}$ show a greater tendency for LGA or macrosomic newborns when weight gain during pregnancy exceeds that recommended by the Institute of Medicine (2009), which occurs more frequently in overweight or obese pregnant women ${ }^{(10,21)}$. In a previous study ${ }^{(10)}$ where all babies were born to overweight or obese women, the macrosomia rate was $2 \%$. In other studies, LGA neonatal rates among pregnant women with GDM ranged from $9.0 \%{ }^{(27)}, 11.22 \%^{(18)}$ to $14.0 \%^{(11)}$, similar to what is described in the present study. The occurrence of newborns with birth weight above 4,000 grams was higher than that of a study ${ }^{(10)}$ related to pregnant women with GDM.

Although in the present study was not found any association between neonatal weight and maternal DM type, other studies $^{(22-23,27-28)}$ do relate birth weight with the occurrence of GDM, showing a greater chance of $\mathrm{LGA}^{(25)}$ or macrosomal ${ }^{(24)}$ births in pregnant women with GDM, even those under drug treatment ${ }^{(25)}$.

The main neonatal complications arising from maternal hyperglycemia involve hypoglycemia, hyperbilirubinemia, hypocalcemia, polycythemia and respiratory disorders ${ }^{(1)}$.

In the present study, $37.6 \%$ of newborns, mostly children of mothers with DM I, had some clinical complication. Unlike these results, studies show a frequency of GDM-related clinical complications from $12 \%^{(27)}$ to $86.8 \%{ }^{(24)}$. Like the need for cardiopulmonary resuscitation ${ }^{(28)}$, neonatal clinical complications may be associated with the diagnosis of DM compared to pregnancies without $\mathrm{DM}^{(24,28)}$. The absolute frequency of respiratory disorders in this study was $27.9 \%$, ranging from $6 \%{ }^{(10)}$ to $40.3 \%{ }^{(24)}$ in newborns of mothers with GDM. There was also a predominance of this neonatal complication in pregnant women with DM compared to those without $\mathrm{DM}^{(24)}$.

The frequency of NICU admissions in this study (8.6\%) was high compared to studies ${ }^{(25,27)}$ that consider only pregnant women with GDM. In addition, NICU admission was associated with the diagnosis of GDM compared to pregnant women without $\mathrm{DM}^{(24,27)}$. In this study, there was an association between neonatal respiratory disorders and DM I, a result also described in another study ${ }^{(19)}$ that compared neonatal outcomes in mothers with DM I and DM II.

\section{Study limitation}

The limitation of this study was that it was a sample of a single neonatology service, even though this service belongs to a reference institution in southern Brazil. The authors recommend the 
development of multicenter studies to increase casuistry, thus providing greater robustness to results.

\section{Contributions to Nursing, Health and Public Politics}

It is necessary to know and consider the possible implications of maternal health conditions on the newborn. In this matter, the present study contributes to increase and improve the knowledge about associations between DM and neonatal conditions at birth. The results of this study may help to improve the best practices during birth, delivery and integral care to newborns, and to prevent complications that may aggravate their health status.

\section{CONCLUSIONS}

This study has shown the influence of maternal nutritional status in DM on the neonatal conditions from birth until the first hour of life. In this context, maternal DM I was associated with lower GA and need for NICU admission, mainly due to respiratory disorder. In addition, overweight or obese mothers had children with higher birth weight and higher incidence of neonatal complications, cardiorespiratory resuscitation, and admission to the NICU due to prematurity.

In this regard, the need for metabolic and nutritional control in pregnant women diagnosed with DM is reiterated, due to the possible occurrence of negative consequences to the newborn.

\section{REFERENCES}

1. American Diabetes Association. Standards of Medical Care in Diabetes [Internet]. Di-abetes Care. 2017 [cited 2018 Jul 15];37(1):S81-90. Available from: http://care.diabetesjournals.org/content/diacare/suppl/2016/12/15/40.Supplement_1.DC1/DC_40_S1_final.pdf

2. Hoeper D, Lonzetti JO, Schmidt SN, Torres MQD. Protocolo de Assistência ao Pré-Natal de Baixo Risco [Internet]. Porto Alegre: Prefeitura Municipal de Porto Alegre. 2015[cited 2018 Jul 15]. Available from: http://lproweb.procempa.com.br/pmpa/prefpoa/sms/usu_doc/ protocolo_pre_natal_2015.pdf

3. Organização Pan-Americana da Saúde. Ministério da Saúde (BR). Federação Brasileira das Associações de Ginecologia e Obstetrícia. Sociedade Brasileira de Diabetes. Brasí-lia, DF, OPAS. Rastreamento e diagnóstico de diabetes mellitus gestacional no Bra-sil[Internet]. 2016 [cited $2018 \mathrm{Jul}$ 15]. Available from: http://www.diabetes.org.br/profissionais/images/pdf/diabetes-gestacional-relatorio.pdf

4. Trujillo J, Vigo A, Reichelt A, Duncan, BB, Schmidt MI. Fasting plasma glucose to avoid a full OGTT in the diagnosis of gestational diabetes. Diabetes Res Clin Pract [In-ternet]. 2014 [cited 2018 Jul 15];105(3):322-6. Available from: http://www.diabetesresearchclinicalpractice.com/ article/S0168-8227(14)00266-6/pdf

5. Hod M, Kapur A, Sacks DA, Hadar E, Agarwal M, Di Renzo GC, et al. The Interna-tional Federation of Gynecology and Obstetrics (FIGO) Initiative on gestational diabe-tes mellitus: A pragmatic guide for diagnosis, management, and care. Int J Gynecol Obstetr [Internet]. 2015 [cited 2018 Jul 15];131(S3). Available from: https://obgyn.onlinelibrary.wiley.com/doi/epdf/10.1016/S0020-7292\%2815\%2930033-3

6. Arizmendi J, Pertuz VC, Colmenares A, Hoyos DG, Palomo T. Diabetes gestacional y complicaciones neonatales. Rev Med [Internet]. 2012[cited 2018 Jul 15];20(2). Avail-able from: https://revistas.unimilitar.edu.co/index.php/rmed/article/view/1200

7. Abi-Abib RC, Cabizuca CA, Carneiro JRI, Braga FO, Cobas RA, Gomes MB, et al. Diabetes na gestação. Rev Hosp Universit Pedro Ernesto [Internet]. 2014 [cited 2018 Jul 15];13(3). Available from: http://revista.hupe.uerj.br/detalhe_artigo.asp?id=494

8. Conselho Nacional de Saúde (Brasil). Resolução n o 466, de 12 de dezembro de 2012. [Internet]. 2012[cited 2018 Jul 15]. Available from: http://bvsms.saude.gov.br/bvs/saudelegis/cns/2013/res0466_12_12_2012.html

9. Atalah E, Castillo C, Castro R, Aldea A. Proposal of a new standard for the nutritional assessment of pregnant women. Rev Med Chile [Internet]. 1997 [cited 2018 Jul 15];125(12):1429-36. Available from: https://www.ncbi.nlm.nih.gov/pubmed/9609018

10. Braz L, Figueiredo L, Fonseca F. A influência da obesidade e ganho ponderal no peso do recém-nascido num grupo de grávidas com diabetes gestacional. Rev Portuguesa Endocrinol, Diabetes e Metabol [Internet]. 2013 [cited 2018 Jul 15];8(2):70-6. Availa-ble from: https:// www.spedmjournal.com/magazine_download.php?id=5

11. Nogueira AI, Santos JSS, Santos LBS, Salomon IMMS, Abrantes MM, Aguiar RALP. Diabetes Gestacional: perfil e evolução de um grupo de pacientes do Hospital das Clí-nicas da UFMG. Revista Médica de Minas Gerais [Internet]. 2011 [cited 2018 Jul 15];21(1):32-41. Available from: http://rmmg.org/artigo/detalhes/288

12. Amaral AR, Silva JC, Ferreira BS, Ribeiro M, Silva AMAB. Impacto do diabetes ges-tacional nos desfechos neonatais: uma coorte retrospectiva. Scien Med [Internet]. 2015 [cited 2018 Jul 15];25(1). Available from: http://revistaseletronicas.pucrs.br/teo/ojs/index.php/scientiamedica/ article/view/19272/12843

13. Albrecht SS, Kuklina EV, Bansil P, Jamieson DJ, Whiteman MK, Kourtis AP, et al. Diabetes trends among delivery hospitalizations in the US, 1994-2004. Diabetes Care [Internet]. 2010 [cited 2018 Jul 15];33(4):768-73. Available from: http://care.diabetesjournals.org/content/ diacare/33/4/768.full.pdf

14. Simeonova-Krstevska, Slagjana, et al. Maternal and neonatal outcomes in pregnant women with gestational diabetes mellitus treated with diet, metformin or insulin. Open Access Macedonian J Med Scienc[Internet]. 2018 [cited 2018 Jul 15];6(5):803-7. Available from: https:// www.ncbi.nlm.nih.gov/pmc/articles/PMC5985864/pdf/OAMJMS-6-803.pdf

15. Alberico S, Montico M, Barresi V, Monasta L, Businelli C, Soini V, et al. The role of gestational diabetes, pre-pregnancy body mass index and gestational weight gain on the risk of newborn macrosomia: results from a prospective multicenter study. BMC Pregnancy 
Childbirth [Internet]. 2014[cited 2018 Jul 15];14(1):23. Available from: https://bmcpregnancychildbirth.biomedcentral.com/track/ pdf/10.1186/1471-2393-14-23

16. Cundy T, Gamble G, Neale L, Elder R, McPherson P, Henley P, et al. Differing causes of pregnancy loss in type 1 and type 2 diabetes. Diabetes Care [Internet]. 2007 [cited 2018 Jul 15];30(10):2603-2607. Available from: http://care.diabetesjournals.org/content/30/10/2603.full-text.pdf

17. Macaulay S, Munthali RJ, Dunger, DB, Norris, SA. The effects of gestational diabetes mellitus on fetal growth and neonatal birth measures in an African cohort. Diabetic Med [Internet]. 2018 [cited 2018 Jul 15];35:1425-33. Available from: https://onlinelibrary.wiley.com/doi/ epdf/10.1111/dme.13668

18. Braga CP, Hirakawa S, Henrique AA. Relationship of weight gain before and during pregnancy with fetal macrosomia in gestation. Rev Soc Bras Alim Nutr [Internet]. 2011 [cited 2018 Jul 15];18610:285. Available from: http://files.bvs.br/upload/S/1519-8928/2011/v36n1/a2490.pdf

19. Hillman N, Herranz L, Vaquero P, Villarroel A, Fernandez A, Pallardo L. Is Pregnancy outcome worse in type 2 than in type 1 diabetic women? Diabetes Care [Internet]. 2006 [cited 2018 Jul 15];29(11):2557-2558. Available from: http://care.diabetesjournals.org/content/29/11/2557. full-text.pdf

20. Simões A, Robalo R, Gomes G, Aleixo F, Amaral N, Guerra S. Diabetes Gestacional nos anos 2000 e 2010: retrato de uma sociedade? Rev Port Endocrinol, Diabetes e Metabol[Internet]. 2013 [cited 2018 Jul 15];8(1):21-24. Available from: https://www.elsevier.es/ en-revista-revista-portuguesa-endocrinologia-diabetes-e-356-estadisticas-S1646343913000047

21. Stuebe A, Boggess K, Berggren E. Excess Maternal Weight Gain and Large for Gesta-tional Age Risk among Women with Gestational Diabetes. Am J Perinatol [Internet]. 2015 [cited 2018 Jul 15];32(03):251-6. Available from: https://www.ncbi.nlm.nih.gov/pmc/articles/PMC4701209/

22. Catalano PM, McIntyre HD, Cruickshank JK, McCance DR, Dyer AR, Metzger BE, et al. The hyperglycemia and adverse pregnancy outcome study: Associations of GDM and obesity with pregnancy outcomes. Diabetes Care [Internet]. 2012 [cited 2018 Jul 15];35(4):780-6. Available from: http://care.diabetesjournals.org/content/35/4/780.full-text.pdf

23. Huynh J, Yamada J, Beauharnais C, Wenger J, Thadhani R, Wexler D, et al. Type 1, type 2 and gestational diabetes mellitus differentially impact placental pathologic characteristics of uteroplacental malperfusion. Placenta [Internet]. 2015 [cited 2018 Jul 15];36(10):1161-6. Available from: http://www.placentajournal.org/article/S0143-4004(15)30031-X/pdf

24. Delgado-Becerra A, Casillas-García DM, Fernández-Carrocera LA. Morbilidad del hijo de madre con diabetes gestacional, en el Instituto Nacional de Perinatología Isidro Es-pinosa de los Reyes. Perinatol Reprod Hum [Internet]. 2011 [cited 2018 Jul 15];25(3):139-145. Available from: http://www.medigraphic.com/pdfs/inper/ip-2011/ip113d.pdf

25. Silva AL, Amaral AR, Oliveira DS, Martins L, Silva MR, Silva, JC. Neonatal outcomes according to different therapies for gestational diabetes mellitus. J Pediatr [Internet]. 2017 [cited 2018 Jul 15];93(1):87-93. Available from: http://www.scielo.br/pdf/jped/v93n1/pt_0021-7557jped-93-01-0087.pdf

26. Ruholamin S, Eshaghian S, Allame Z. Neonatal outcomes in women with gestational diabetes mellitus treated with metformin in compare with insulin: A randomized clini-cal trial. J Res Med Sci [Internet]. 2014 [cited 2018 Jul 15];19(10):970. Available from: https://www.ncbi.nlm. nih.gov/pmc/articles/PMC4274575/

27. Aktün HL, Uyan D, Yorgunlar B, Acet M. Gestational diabetes mellitus screening and outcomes. J Turkish-German Gynecol Assoc [Internet]. 2015 [cited 2018 Jul 15];16(1):25-9. Available from: https://www.ncbi.nlm.nih.gov/pmc/articles/PMC4358307/

28. Grandi C, Tapia J, Cardoso V. Impact of maternal diabetes mellitus on mortality and morbidity of very low birth weight infants: a multicenter Latin America study. J Pedi-atr [Internet]. 2015 [cited 2018 Jul 15];91(3):234-41. Available from: https://www.scielo.br/pdf/jped/v91n3/00217557-jped-91-03-00234.pdf 